\title{
High methane emissions dominated annual greenhouse gas balances 30 years after bog rewetting
}

\author{
M. Vanselow-Algan ${ }^{1}$, S. R. Schmidt ${ }^{2}$, M. Greven ${ }^{1}$, C. Fiencke ${ }^{1}$, L. Kutzbach ${ }^{1}$, and E.-M. Pfeiffer ${ }^{1}$ \\ ${ }^{1}$ University of Hamburg, Center for Earth System Research and Sustainability, Institute of Soil Science, Hamburg, Germany \\ ${ }^{2}$ University of Hamburg, Biocenter Klein Flottbek, Applied Plant Ecology, Hamburg, Germany \\ Correspondence to: M. Vanselow-Algan (marion.vanselow-algan@uni-hamburg.de)
}

Received: 16 December 2014 - Published in Biogeosciences Discuss.: 10 February 2015

Accepted: 1 July 2015 - Published: 28 July 2015

\begin{abstract}
Natural peatlands are important carbon sinks and sources of methane $\left(\mathrm{CH}_{4}\right)$. In contrast, drained peatlands turn from a carbon sink to a carbon source and potentially emit nitrous oxide $\left(\mathrm{N}_{2} \mathrm{O}\right)$. Rewetting of peatlands thus potentially implies climate change mitigation. However, data about the time span that is needed for the re-establishment of the carbon sink function by restoration are scarce. We therefore investigated the annual greenhouse gas (GHG) balances of three differently vegetated sites of a bog ecosystem 30 years after rewetting. All three vegetation communities turned out to be sources of carbon dioxide $\left(\mathrm{CO}_{2}\right)$ ranging between $0.6 \pm 1.43 \mathrm{t} \mathrm{CO}_{2} \mathrm{ha}^{-2} \mathrm{yr}^{-1} \quad$ (Sphagnum-dominated vegetation) and $3.09 \pm 3.86 \mathrm{t} \mathrm{CO}_{2} \mathrm{ha}^{-2} \mathrm{yr}^{-1}$ (vegetation dominated by heath). While accounting for the different global warming potential (GWP) of $\mathrm{CO}_{2}, \mathrm{CH}_{4}$ and $\mathrm{N}_{2} \mathrm{O}$, the annual GHG balance was calculated. Emissions ranged between 25 and $53 \mathrm{tCO}_{2}$-eq ha ${ }^{-1} \mathrm{yr}^{-1}$ and were dominated by large emissions of $\mathrm{CH}_{4}\left(22-51 \mathrm{tCO}_{2}\right.$-eq ha $\left.{ }^{-1} \mathrm{yr}^{-1}\right)$, with highest rates found at purple moor grass (Molinia caerulea) stands. These are to our knowledge the highest $\mathrm{CH}_{4}$ emissions so far reported for bog ecosystems in temperate Europe. As the restored area was subject to large fluctuations in the water table, we assume that the high $\mathrm{CH}_{4}$ emission rates were caused by a combination of both the temporal inundation of the easily decomposable plant litter of purple moor grass and the plant-mediated transport through its tissues. In addition, as a result of the land use history, mixed soil material due to peat extraction and refilling can serve as an explanation. With regards to the long time span passed since rewetting, we note that the initial increase in $\mathrm{CH}_{4}$ emissions due to rewetting as described in the literature is not inevitably limited to a shortterm period.
\end{abstract}

\section{Introduction}

Covering only $3 \%$ of the Earth's land surface, peatlands store as much carbon as all terrestrial biomass and twice as much as all global forest biomass (Parish et al., 2008). Today, merely $1 \%$ of the former peatlands areas in western Europe still has living mire vegetation and accumulates peat (Koster and Favier, 2005). An area of 80 million ha of peatlands have been destroyed worldwide, mainly due to drainage for agriculture and forestry, and due to peat mining for fuel and horticulture (Joosten and Clarke, 2002). While growing mires have a cooling effect on the climate by acting as a carbon sink, degraded peatlands are a major and growing source of the greenhouse gases (GHG) carbon dioxide $\left(\mathrm{CO}_{2}\right)$ and nitrous oxide $\left(\mathrm{N}_{2} \mathrm{O}\right.$; Joosten et al., 2012).

$\mathrm{CO}_{2}$ emissions from degraded peatlands are estimated to be equivalent to more than $10 \%$ of global fossil fuel emissions (Parish et al., 2008). Even in an industrialized country, such as Germany, does the estimated peatland GHG exchange account for $2.3-4.5 \%$ of the anthropogenic emissions (Drösler et al., 2008). Therefore, restoration of peatlands includes not only the recovery of ecosystem functions and biodiversity, but also climate change mitigation (Drösler et al., 2009). Rewetting of drained peat soils as climate change mitigation measure presents a new challenge (Erwin, 2009; Couwenberg, 2009): in Germany, a potential reduction of 35 million tons $\mathrm{CO}_{2}$ equivalent per year is possible through peatland restoration, which is a cost-effective mitigation strategy (Joosten, 2006; Drösler et al., 2009; Freibauer et al., 2009). However, rewetting of peatlands leads to increased methane emissions by both reduced methane oxidation and increased methane production (Komulainen et al., 
1998; Tuittila et al., 2000; Waddington and Day, 2007; Wilson et al., 2009; Cooper et al., 2014). Flooding of peat soils for restoration should be avoided as inundation leads to huge $\mathrm{CH}_{4}$ emissions especially if fresh plant litter is available (Augustin and Joosten, 2007; Drösler et al., 2008; Hahn-Schöfl et al., 2011). Although these high $\mathrm{CH}_{4}$ emissions are generally assumed to be a transient phenomenon of limited duration (Morison, 2012; Joosten et al., 2012; Artz et al., 2013; Cooper et al., 2014), no information exists on the length of this time span after rewetting (Augustin and Joosten, 2007). Nevertheless, the term "short-term" is often used in grey literature (Trepel, 2008; Morison, 2012). Moreover, there is high uncertainty about the magnitude of $\mathrm{CH}_{4}$ fluxes in peatlands (Joabsson et al., 1999). However, it is generally agreed that vascular plants stimulate $\mathrm{CH}_{4}$ emissions by allowing the gas to bypass the oxygenated upper soil layer moving through the plant tissues (Joabsson et al., 1999; Kutzbach et al., 2004; Lai, 2009). This plant-mediated transport can represent between 30 and almost $100 \%$ of the total methane flux (Bhullar et al., 2013). Plants that provide such a shortcut between the root zone and the atmosphere are referred to as "shunt" species (Joosten et al., 2012). Many studies linked the increase of $\mathrm{CH}_{4}$ emissions post-restoration to the colonization of the rewetted area by Eriophorum species (Tuittila et al., 2000; Waddington and Day, 2007; Green and Baird, 2012; Cooper et al., 2014).

In the future, restoration and management of peatlands will be more complex and challenging due to climate change (Erwin, 2009; Grand-Clement et al., 2013). Thus, extensive knowledge of peat soil processes will help in the adaptation of management practices and in turn in stabilization of ecosystem functions of peatlands against new environmental threats. However, data about the $\mathrm{C}$ balance of restored and abandoned peatlands is scarce on national and global scales and is urgently needed (Yli-Petäys et al., 2007; Artz et al., 2013). As most studies focus on the boreal region or are conducted mainly at recently rewetted sites (Beyer and Höper, 2015), research on the mid- and long-term effect of rewetting is essential, especially in temperate peatlands.

We studied the $\mathrm{CO}_{2}$ and GHG balances of three different plant communities at a regenerating mined area and of the active peat extraction site within the same ombrotrophic peatland in northern Germany. Our main goal was to investigate if restoration succeeded in creating a $\mathrm{CO}_{2}$ sink and to estimate the GHG mitigation potential of restoring the industrial peat extraction site after abandonment. We hypothesized that the restored site acted as a $\mathrm{CO}_{2}$ sink with varying magnitude depending on plant community. Likewise, we expected that higher $\mathrm{CH}_{4}$ emissions were related to high abundance of vascular plant species and thus varied between the three plant communities. On the other hand, no significant $\mathrm{N}_{2} \mathrm{O}$ fluxes were expected on the vegetated sites. Testing theses hypotheses could provide recommendations for site-specific management actions, because peat mining of the study area will be ceased in a few years.

\section{Material and methods}

\subsection{Study area Himmelmoor}

The Himmelmoor (Quickborn, Germany; 534ㄴ $24^{\prime \prime} \mathrm{N}$, $9^{\circ} 50^{\prime} 58^{\prime \prime} \mathrm{E}$ ) is located approximately $20 \mathrm{~km}$ northwest of Hamburg in Schleswig-Holstein. The mean annual precipitation measured at the climate station in Quickborn is $838 \mathrm{~mm}$, and the mean air temperature is $9.0^{\circ} \mathrm{C}$ (long-term average from 1981 to 2010, data source: Deutscher Wetterdienst). Climatically, there was $821 \mathrm{~mm}$ of precipitation and an average temperature of $9.6^{\circ} \mathrm{C}$ during study year 2011 , very close to the long-term average. We therefore consider our measurements as representative for the present climatic conditions.

With an extent of about $6 \mathrm{~km}^{2}$, the Himmelmoor is one of the largest raised bogs in Schleswig-Holstein. Peat formation by terrestrialization started after the last ice age $10.020 \pm 100$ years before present and the total peat thickness reached a maximum of $10 \mathrm{~m}$ (Pfeiffer, 1998; Grube et al., 2010). The original ombrotrophic peat bog was altered by peat drainage and cutting began in the 18th century. Commercial peat mining started in 1871 (Averdieck, 1957) and persists to this day. According to the peat mining company, a volume of $38000 \mathrm{~m}^{3}$ of peat was harvested in the study year 2011 over an area of 70 ha of the former 130 ha extraction site $(\mathrm{K}$. Czerwonka, personal communication, 2013). Peat mining will cease in 2016 due to the exhaustion of usable peat resources, and restoration will take place.

\subsection{Measurement sites}

Measurements were done on the bare and deeply drained active peat extraction site and on a restored and vegetated part in the northwestern Himmelmoor. All soils are classified as Fibric Ombric Histosol, while for the peat extraction site, the suffix qualifier Drainic applies in addition (IUSS, 2006). The restored site was formerly used by hand block-cutting for fuel. Before cutting the drained black peat, the upper rooted layer called Bunkerde (Poschlod, 1988) was removed and used for filling up cut-over areas as described in Koster and Favier (2005). In the 1960s the site was abandoned and vegetation development started, mainly from whole plants or generative and vegetative propagules in the Bunkerde. Restoration began in the 1980s with drainage blocking and the repeated cutting of birches (last event: 2008) in order to raise the water table. Today, the strips between former drainage ditches (distance: $30-45 \mathrm{~m}$ ) show differences in plant species composition. Three strips with differing vegetation, typical for rewetted peatlands, were chosen and named after the most prominent plant species or groups, later referred to as "heath", "Sphagnum" or "purple moor grass" site. According to the decimal scale of Londo (1976), plotwise analyzes of vascular plant species were done in the study year 2011 during summertime, providing vegetation coverage and abundance to confirm the visual classification of these sites. The 
moss cover was determined using pointintercept sampling as described in Jonasson (1988), with the following categories: Sphagnum mosses, other mosses, liverworts and bare peat.

GHG fluxes were measured at each of the four sites in four replicates (plots). Therefore, PVC frames $(60 \mathrm{~cm} \times 60 \mathrm{~cm})$ with a soil insertion depth of about $50 \mathrm{~cm}$ were permanently installed blockwise. Positions were selected based on vegetation and microtopography with the intention of representing the whole site. All plots of the vegetated site were equipped with wooden boardwalks to minimize soil gas disturbances during flux measurements. Boardwalks were oriented northwards of the plots to avoid shading. Several micrometeorological variables were continuously monitored at a central point of the restored site, including air temperature and air pressure, photosynthetically active radiation (PAR), wind speed and wind direction (all at $2 \mathrm{~m}$ height) and precipitation. Water table depth and soil temperature $(10 \mathrm{~cm}$ depth) were measured at each site except for the peat extraction site.

\subsection{Chamber design and flux measurement procedure}

GHG flux measurements were done using closed chambers. Their design conforms to the latest recommendations for chamber design made by Pihlatie et al. (2013). $\mathrm{CO}_{2}$ fluxes were measured with a transparent, climate-controlled chamber system connected to an infrared gas analyzer (IRGA, LI840, LI-COR inc.) as described by Schneider et al. (Schneider et al., 2011). Additionally, the chamber was equipped with a PAR sensor inside. Measurements were done for 3 min, recording $\mathrm{CO}_{2}$ concentration, PAR and chamber air temperature every second. To gain a wide spectrum of different light conditions for modeling, the transparent chamber was shaded in two intensities with black gauze (Elsgaard et al., 2012; Görres et al., 2014). After the first measurement with the transparent chamber, a second measurement was performed while shading the chamber with one layer of gauze (PAR approx. $50 \%$ ) and a third measurement was done with two layers (PAR approx $30 \%$ ). Subsequently, the chamber was darkened in a fourth measurement with an opaque cover $(\mathrm{PAR}=0)$ to estimate ecosystem respiration (Reco). Between each measurement the chamber was removed and ventilated to obtain ambient $\mathrm{CO}_{2}$ concentrations within the chamber. If vegetation exceeded chamber height, a transparent polycarbonate elongation of $60 \mathrm{~cm}$ height was used, which was shaded and darkened correspondingly. Measurements were generally conducted between 10:00 and 14:00 local time when PAR reached the maximum, and the measuring order of the sites was randomized. $\mathrm{CO}_{2}$ flux measurements were performed year-round from August 2010 until January 2012. Measurement intervals depended on vegetation growth with higher frequency in summer than in winter (at least twice a month up to twice a week). To compare day and night respiratory fluxes, nighttime measurements were taken three times during the night of 30-31 August 2011 (around 21:00, 00:00 and 05:00). $\mathrm{CH}_{4}$ and $\mathrm{N}_{2} \mathrm{O}$ flux mea- surements were performed over a 1-year period from April 2011 until March 2012. Measurements were carried out every 2 weeks (except December 2011: once per month) for $\mathrm{CH}_{4}$ and monthly for $\mathrm{N}_{2} \mathrm{O}$ as first results showed no significant $\mathrm{N}_{2} \mathrm{O}$ fluxes. $\mathrm{CH}_{4}$ was measured at all four replicate plots, $\mathrm{N}_{2} \mathrm{O}$ only at three. Nighttime measurements were performed during the night of 30 to 31 August 2011 around midnight. $\mathrm{CH}_{4}$ and $\mathrm{N}_{2} \mathrm{O}$ flux measurements were done using aluminum chambers $(60 \mathrm{~cm} \times 60 \mathrm{~cm} \times 32 \mathrm{~cm}$; an elongation of $60 \mathrm{~cm}$ was used if needed) which were equipped with a fan, a pressure vent, a temperature sensor and a sampling port. Two circular openings ( $4 \mathrm{~cm}$ diameter) at the front side were open while placing the chamber on the collar and closed afterwards to reduce initial pressure shocks (Schneider et al., 2009). During the closure time of $20 \mathrm{~min}$, six samples were taken from the chamber headspace with $60 \mathrm{~mL}$ plastic syringes connected to the sampling port via three-way stopcocks.

$\mathrm{CH}_{4}$ samples were analyzed subsequently in the lab using a gas chromatograph (GC) equipped with a flame ionization detector (HP 5890 Packard Series II). Syringes were directly connected via a loop. Analyses were done within 4 days after sampling, and each sample was analyzed twice. Two standard gases were used for calibration (1.7 and $200 \mathrm{ppm} \mathrm{CH}_{4}$ ), injected in triplicates before and after samples of three plots.

$\mathrm{N}_{2} \mathrm{O}$ was measured at a GC provided with an electron capture detector (Agilent Technologies 7890A). In the field, a sample volume of $20 \mathrm{~mL}$ was injected into an air-filled septum vial, from where it was then taken with a microliter syringe and injected into the GC. The GC was calibrated daily with three standard gases $\left(0.3,0.9\right.$ and $\left.1.5 \mathrm{ppm} \mathrm{N}_{2} \mathrm{O}\right)$ being injected in triplicates before measurement. Since the samples were diluted by injecting them into the air-filled vials, standards were treated similarly to have the appropriate concentration. As this procedure might cause a decrease in accuracy, it was tested with a standard gas. There was no decrease in reproducibility in comparison to a standard gas that was injected directly into the GC: the coefficient of variation was 0.01 in both cases $(N=10)$.

\subsection{Flux calculation}

The GHG flux rates were calculated from the change in gas concentration as a function of time during chamber closure. Gross primary production (GPP) was calculated as the difference between the directly following measurements with transparent and dark chambers, respectively. According to the micrometeorological sign convention, positive values represent fluxes to the atmosphere and negative values uptakes by the ecosystem.

Flux calculation of each single $\mathrm{CO}_{2}$ chamber measurement was done with an updated version of the MATLAB ${ }^{\circledR}$ routine of Kutzbach et al. (2007) using a power series expansion of a nonlinear regression as described by Görres et al. (2014). The first and the last 10 of the $180 \mathrm{~s}$ of each mea- 
surement were discarded and the flux rate was calculated at $t=10 \mathrm{~s}$ from the remaining $160 \mathrm{CO}_{2}$ concentration data points applying a water vapor dilution correction. Each single flux curve was reviewed for abnormalities such as abrupt changes in slope due to, e.g., changes in PAR derived from cloud movement. If possible, the flux was recalculated by using only a part of the $160 \mathrm{~s}$ interval with constant conditions (minimum $40 \mathrm{~s}$ ). Flux calculations with outlying residuals were checked for mistakes, e.g., in data preparation, and were discarded from the data set if the mistake could not be eliminated. The standard deviation of the residuals of most of the data (98\%) was lower than $0.55 \mathrm{ppm}$ and had a mean of $0.42 \pm 0.06 \mathrm{ppm}$, which is remarkably low as the noise of the IRGA is specified to be $<1 \mathrm{ppm}$. Upward concave flux curves, which are not explainable by diffusion theory were calculated using linear regression as executed by Schneider et al. (2011). It was shown that this procedure achieves more robust and less biased flux estimates (Schäfer, 2012; Görres et al., 2014).

Flux calculation of each $\mathrm{CH}_{4}$ and $\mathrm{N}_{2} \mathrm{O}$ chamber measurement was done with an updated version of the MATLAB ${ }^{\circledR}$ routine of Forbrich et al. (2010). Each single flux curve was reviewed for abnormalities such as ebullition and discarded from data set if necessary. Linear or nonlinear regression was used depending on the model performances according to the Akaike information criterion. As only six concentration measurements were available for flux calculation, we used the Akaike information criterion with small sample correction (AICc), as proposed by Forbrich et al. (2010). According to AICc, the majority of $\mathrm{CH}_{4}$ and $\mathrm{N}_{2} \mathrm{O}$ fluxes curves was better explained by linear than by exponential regression (74 and $98 \%$, respectively).

\subsection{Flux modeling}

Net ecosystem exchange (NEE), Reco and GPP were modeled over a complete year (2011). Modeling of GPP and Reco was based on ambient PAR and air temperature, respectively, which were measured half-hourly at the meteorological station. Each single plot $(N=16)$ was modeled separately to analyze the differences between and within the sites. Values of the four plots per site were later averaged, thus standard deviations shown here display the spatial variability of flux estimates. As day and night fluxes of $\mathrm{CO}_{2}, \mathrm{CH}_{4}$ and $\mathrm{N}_{2} \mathrm{O}$ were not statistically different, modeling was only based on daytime data.

GPP was modeled with a rectangular hyperbolic light response curve as described in Elsgaard et al. (2012) using PAR values from inside the chamber (GPP 1 model, Table 1). Applying this curve obtains light saturation points $\left(P_{\max }\right)$ for a certain period of the year (1 week up to 1 month depending on measurement interval and season). Gap filling between these intervals was done using linear interpolation. If GPP 1 could not explain the data appropriately, a linear model was used instead (GPP 2, Table 1). In wintertime when GPP ranged around zero, neither of the two models could be fitted and mean values were used instead.

To estimate annual Reco fluxes, we used air and soil temperature as explanatory variables and tested two different models (Table 1), using all respiratory flux data of the study year for each plot. Comparing the qualifying parameter $R_{\text {adjusted }}^{2}$ of the model results showed that the respiratory fluxes were better explained by air than by soil temperature and that Reco 1 model achieved better results than Reco 2 model. The annual Reco fluxes of the industrial extraction site were estimated using linear regression, as both models resulted in low $R_{\text {adjusted }}^{2}$ values ranging between 0.03 and 0.33 .

Methane fluxes did not show a soil temperature or water table depth dependency. Annual fluxes were thus not modeled with the classical model of Saarnio et al. (1997) as intended, but calculated with linear interpolation, as done for the annual $\mathrm{N}_{2} \mathrm{O}$ flux rates.

\subsection{Calculation of the GHG budget}

For the calculation of the GHG budget, the fluxes of $\mathrm{CH}_{4}$ and $\mathrm{N}_{2} \mathrm{O}$ were converted in $\mathrm{CO}_{2}$ equivalent according to their global warming potentials on a 100 -year timescale including climate-carbon feedbacks: $\mathrm{CH}_{4}=34$ and $\mathrm{N}_{2} \mathrm{O}=298$ (IPCC, 2013). The $C$ loss due to peat mining was also estimated in $\mathrm{CO}_{2}$ equivalent. The calculation was based on the amount of peat harvested in the study year relative to bulk density and $\mathrm{C}$ content of the peat, measured within the upper three soil horizons.

\section{Results}

\subsection{Water table}

The four sites displayed differences in water table depth throughout the year (Fig. 1). The Sphagnum site had the highest water table followed by the heath and the purple moor grass site with an annual mean for 2011 of $1.2,-0.8$ and $-2.7 \mathrm{~cm}$, respectively. The lowest water table was recorded at the drained active industrial extraction site with a minimum of $55 \mathrm{~cm}$ under the soil surface and a mean of $-23 \mathrm{~cm}$ for a 12-month period from April 2011 to March 2012. The industrial extraction site faces a great range of water table amplitude. In contrast, the variation in the water table depth of the three vegetated sites was much less, but soil surfaces were often inundated especially in the winter half of the year.

\subsection{Vegetation}

The vegetation analysis showed clear differences in species coverage between the three defined sites (Table 2). The heath site was dominated by ericaceous shrubs $(49 \%$ cumulative coverage of Erica tetralix, Calluna vulgaris, Vaccinium oxycoccos and Andromeda polifolia). The Sphagnum site had 
Table 1. Two model approaches for gross primary production (GPP) as a function of photosynthetically active radiance (PAR) and two temperature-driven ecosystem respiration (Reco) models, where $t=$ air or soil temperature, respectively, and $a, b$ and $c$ are fitting parameters.

\begin{tabular}{|c|c|c|}
\hline Model title & Model formula & Remarks \\
\hline GPP 1 & $\mathrm{GPP}=\frac{P_{\max } \alpha \mathrm{PAR}}{P_{\max }+\alpha \mathrm{PAR}}$ & $\begin{array}{l}\text { Rectangular hyperbolic function } \\
\text { (Schäfer, 2012; Elsgaard et al., 2012). } \\
P_{\max }=\text { maximum potential photosynthetic rate, } \\
\alpha=\text { initial light response efficiency. }\end{array}$ \\
\hline GPP 2 & $\mathrm{GPP}=a+b \mathrm{PAR}$ & Linear model, $a$ and $b$ are fitting parameters. \\
\hline Reco 1 & $\operatorname{Reco}=\frac{a}{1+b e-k t}$ & $\begin{array}{l}\text { Simple logistic function (Richards, 1959; } \\
\text { Rodeghiero and Cescatti, 2005; Schäfer, 2012). }\end{array}$ \\
\hline Reco 2 & $\operatorname{Reco}=a e^{b t}$ & $\begin{array}{l}\text { Two-parameter exponential function } \\
\text { (Schneider et al., 2009; Schäfer, 2012) }\end{array}$ \\
\hline
\end{tabular}

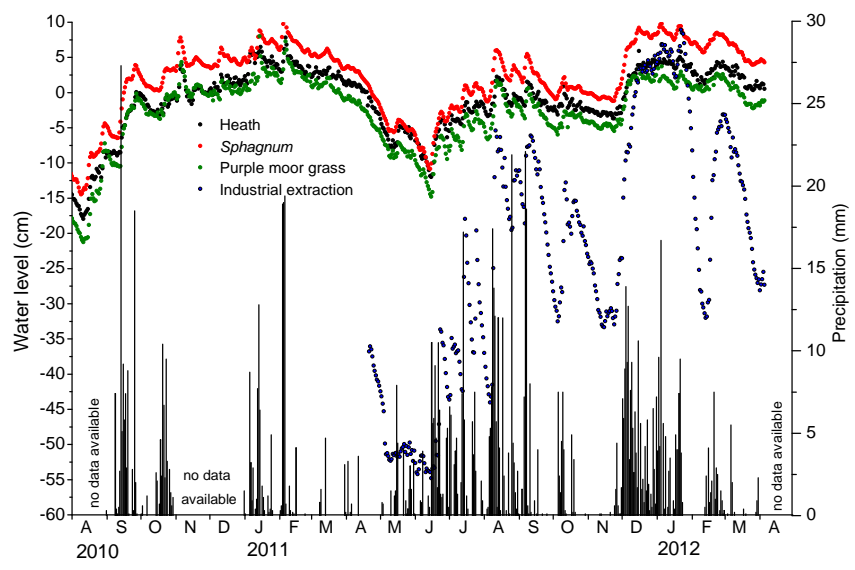

Figure 1. Mean daily water table and daily precipitation at four different bog sites over the whole measurement period from July 2010 until April 2012. No data available for the industrial extraction site before April 2011. Negative values indicate water levels below soil surface and positive values indicate inundation.

$99 \%$ coverage of Sphagnum mosses (mainly S. cuspidatum and $S$. fimbriatum) and the purple moor grass site was dominated by the perennial deciduous grass Molinia caerulea (67\% coverage). Sites additionally differed in the number of vascular plant species decreasing in the following order: heath > Sphagnum > purple moor grass with in total nine, eight and six species, respectively.

\subsection{NEE model}

The results of the modeled Reco (Fig. 2) and the modeled GPP were summed up resulting in modeled net ecosystem exchange (NEE; Fig. 3). The temporal dynamics between the sites were quite similar for the heath and the Sphagnum site. However, the Sphagnum site displayed some more pronounced peaks in photosynthesis. The purple moor grass site had a steep increase in photosynthesis in May and was very productive in summertime, while photosynthesis at the two other vegetated sites began earlier and with a slower in-

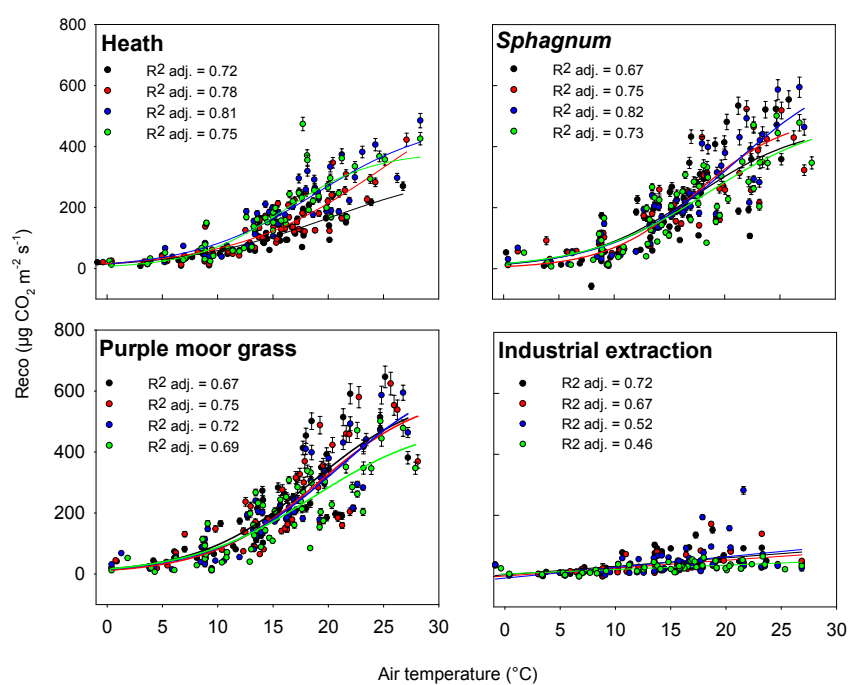

Figure 2. Measured ecosystem respiration (Reco) as a function of air temperature. Points indicate fluxes \pm standard error of the flux calculation. The replicate plots of each site are shown in different colors. Lines represent the fits to raw data using Reco 1 model. For the industrial extraction site a linear regression was used. The goodness-of-fit is indicated ( $\left.R_{\text {adjusted }}^{2}\right)$.

crease. Before the steep increase in photosynthesis at the purple moor grass site, respiratory fluxes predominated and increased from March until May. The industrial extraction site was characterized by comparatively low respiratory fluxes.

\section{4 $\mathrm{CO}_{2}$ budget}

The annual net ecosystem exchange (NEE) in 2011 was positive at all vegetated sites as well as at the industrial extraction site (Fig. 4), meaning a net $\mathrm{CO}_{2}$ release from the ecosystem. The highest values of NEE were determined at the active industrial extraction site where ecosystem respiration predominates $\left(730 \pm 67 \mathrm{~g} \mathrm{~m}^{2} \mathrm{yr}^{-1}\right)$, followed by heath, purple moor grass and Sphagnum with $308 \pm 386,247.36 \pm 330.29$ and 
Table 2. Average coverage of vascular plant species according to Londo (1976) at the three rewetted bog sites in 2011. Coverage of the moss layer and bare peat areas were estimated using pointintercept sampling (Jonasson, 1988). Values refer to means of 7-8 replicates \pm SD. Numbers in bold print indicate eponymous species for site denotation. Sphagnum species were mainly S. cuspidatum and S. fimbriatum. A dash indicates that the species was not found.

\begin{tabular}{lrrr}
\hline Plant species coverage (\%) & Heath & Sphagnum & Purple moor grass \\
\hline Eriophorum angustifolium & $16.9 \pm 8.4$ & $45.7 \pm 29.2$ & $3.4 \pm 3.9$ \\
Molinia caerulea & $1.3 \pm 1.8$ & $18.4 \pm 21.2$ & $\mathbf{6 6 . 9} \pm \mathbf{1 5 . 6}$ \\
Erica tetralix & $\mathbf{3 0 . 6} \pm \mathbf{1 9 . 0}$ & $5.7 \pm 8.4$ & - \\
Calluna vulgaris & $14.4 \pm 18.0$ & $0.9 \pm 1.9$ & $1.4 \pm 3.5$ \\
Eriophorum vaginatum & $5.1 \pm 5.1$ & $2.4 \pm 3.8$ & $0.1 \pm 0.4$ \\
Vaccinium oxycoccos & $1.6 \pm 1.7$ & $0.7 \pm 1.9$ & - \\
Andromeda polifolia & $2.5 \pm 3.8$ & - & - \\
Betula pubescens & $2.0 \pm 3.3$ & $1.4 \pm 3.0$ & $1.4 \pm 1.6$ \\
Drosera rotundifolia & $0.3 \pm 0.5$ & $0.3 \pm 0.5$ & - \\
Juncus spec. & - & - & $0.3 \pm 0.5$ \\
\hline Sphagnum mosses & $23.6 \pm 35.9$ & $\mathbf{9 8 . 9} \pm \mathbf{3 . 0}$ & $17.7 \pm 14.8$ \\
Liverworts & $33.0 \pm 37.9$ & - & $13.2 \pm 18.0$ \\
Other mosses & $39.6 \pm 43.5$ & $1.1 \pm 3.0$ & $5.6 \pm 10.6$ \\
Bare peat & $2.4 \pm 6.9$ & - & $22.2 \pm 15.1$ \\
\hline
\end{tabular}

Table 3. Mean annual $\mathrm{CH}_{4}$ and $\mathrm{N}_{2} \mathrm{O}$ fluxes $\pm \mathrm{SD}$ at four different bog sites. Values refer to means of four replicates $\pm \mathrm{SD}$.

\begin{tabular}{lrr}
\hline Site & $\mathrm{CH}_{4}\left(\mu \mathrm{g} \mathrm{m}^{-2} \mathrm{~s}^{-1}\right)$ & \multicolumn{1}{c}{$\mathrm{N}_{2} \mathrm{O}\left(\mu \mathrm{g} \mathrm{m}^{-2} \mathrm{~s}^{-1}\right)$} \\
\hline Heath & $2.02 \pm 0.41$ & $-0.0008 \pm 0.0038$ \\
Sphagnum & $3.16 \pm 2.20$ & $0.0017 \pm 0.0021$ \\
Purple moor grass & $4.71 \pm 3.32$ & $-0.0013 \pm 0.0038$ \\
Industrial extraction & $0.01 \pm 0.02$ & $0.0165 \pm 0.0086$ \\
\hline
\end{tabular}

$59.56 \pm 142.58 \mathrm{~g} \mathrm{~m}^{2} \mathrm{yr}^{-1}$, respectively. These differences in NEE between the sites were closely approximating significance (ANOVA, $p=0.055$ ).

\section{5 $\mathrm{CH}_{4}$ and $\mathrm{N}_{2} \mathrm{O}$ fluxes}

$\mathrm{CH}_{4}$ emissions showed no seasonal trend and were not dependent on water level or soil temperature (data not shown). However, $\mathrm{CH}_{4}$ fluxes differed significantly among sites (ANOVA, $p<0.00$ ): $\mathrm{CH}_{4}$ fluxes of the industrial extraction site ranged around zero, while the vegetated sites acted as $\mathrm{CH}_{4}$ sources. $\mathrm{CH}_{4}$ emissions increased in the following order (Table 3): heath < Sphagnum < purple moor grass. $\mathrm{N}_{2} \mathrm{O}$ fluxes were significantly different between the industrial extraction site and the vegetated sites (ANOVA, $p=0.002$ ). Significant emission of $\mathrm{N}_{2} \mathrm{O}$ were only measured at the industrial extraction site at summertime, resulting in mean annual emissions of $0.0165 \pm 0.0086 \mu \mathrm{g} \mathrm{m}^{-2} \mathrm{~s}^{-1}$. $\mathrm{N}_{2} \mathrm{O}$ fluxes of the rewetted sites were very low, ranging around zero and varying between small uptakes and emissions throughout the whole year.

\subsection{Greenhouse gas balance}

$\mathrm{CH}_{4}$ and $\mathrm{N}_{2} \mathrm{O}$ fluxes were calculated into $\mathrm{CO}_{2}$ equivalent $\left(\mathrm{CO}_{2}\right.$-eq) and summed with the $\mathrm{CO}_{2}$ fluxes as a GHG budget (Table 4). We found that all sites were significant sources of greenhouse gases. The GHG balance of the rewetted sites was dominated by $\mathrm{CH}_{4}$ emissions, accounting for $88-98 \%$ of the total GHG $\mathrm{CO}_{2}$-eq emissions. The portion of $\mathrm{N}_{2} \mathrm{O}$ was negligible there, while it played with about $21 \%$ of the GHG balance a significant role at the industrial extraction site $\left(1.55 \pm 0.81 \mathrm{tCO}_{2}\right.$-eq $\left.\mathrm{ha}^{-1} \mathrm{yr}^{-1}\right)$. The uncertainty of the GHG budget was high due to high spatial variability between the replicates. Nevertheless, differences between the sites were statistically different $(\mathrm{p}<0.05$, Kruskal-Wallis one way ANOVA). The highest GHG emissions were detected at the purple moor grass site $\left(53.05 \pm 35.72 \mathrm{tCO}_{2}\right.$-eq ha ${ }^{-1}$ $\left.\mathrm{yr}^{-1}\right)$, whereas the lowest GHG emissions were present at the industrial extraction site $\left(8.9 \pm 1.1 \mathrm{tCO}_{2}\right.$-eq ha $\left.{ }^{-1} \mathrm{yr}^{-1}\right)$. However, the GHG balance of the industrial extraction site is not complete without considering the amount of mined peat. Including these $\mathrm{C}$ losses and assuming their release as $\mathrm{CO}_{2}$, the GHG balance of the industrial extraction site was considerably higher than those of the vegetated sites $\left(123 \pm 7 \mathrm{tCO}_{2}\right.$-eq ha $\left.{ }^{-1} \mathrm{yr}^{-1}\right)$.

\section{Discussion}

The visual differences in plant communities between the three sites were confirmed by analyses of species composition and coverage. Additionally, different life forms dominated, emphasizing diverse functions and adaptations to the ecosystem: evergreen, ericaceous shrubs (heath site), 


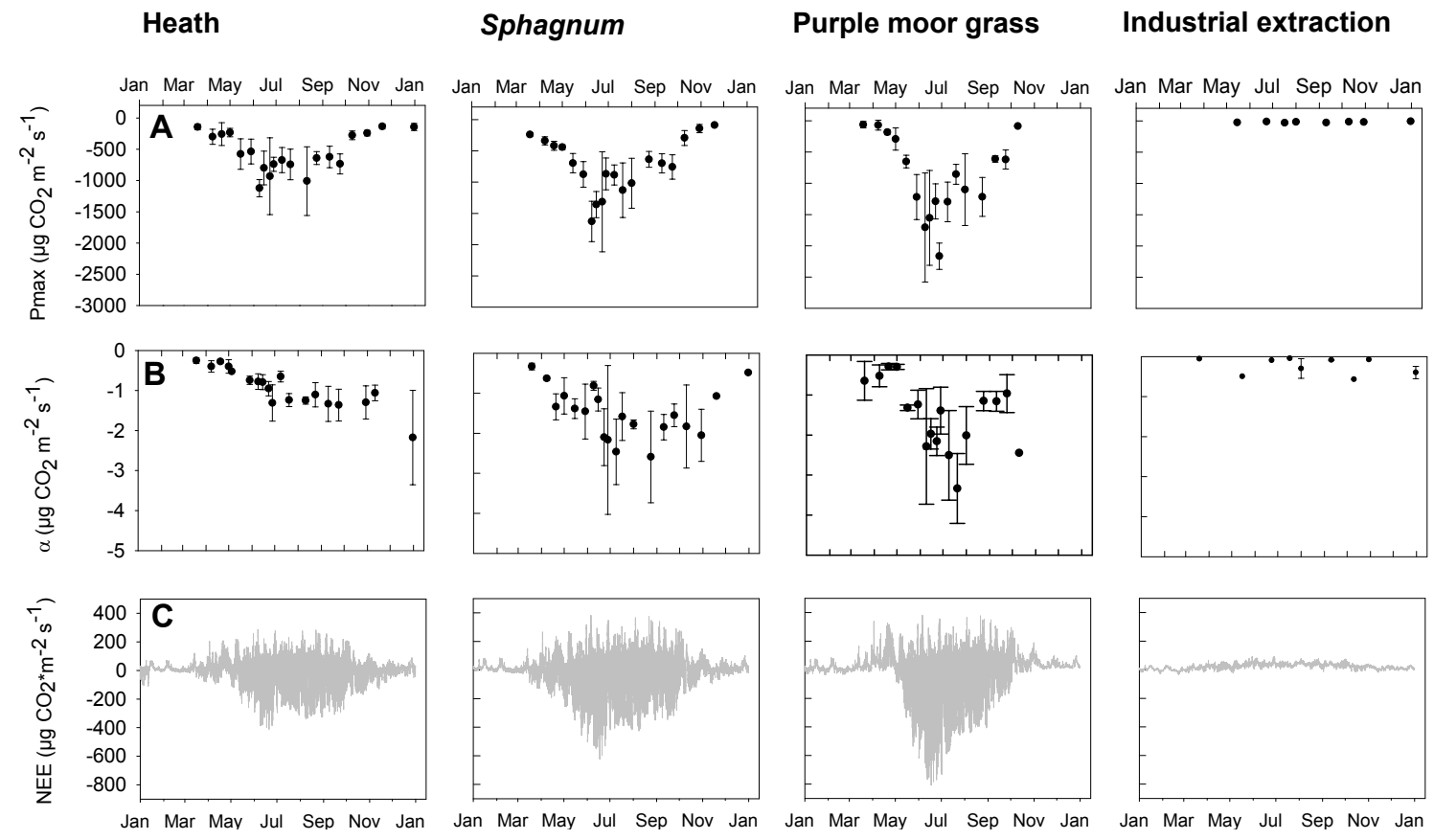

Figure 3. Model parameters for gross primary production (GPP 1 model) in 2011: (a) maximum photosynthetic activity ( $\left.P_{\text {max }}\right)$ and (b) values for the initial light response efficiency $(\alpha)$. Points indicate means of four replicate plots \pm SD. (c) Mean modeled net ecosystem exchange $(\mathrm{NEE})$ in 2011. Positive values represent emissions and negative values uptakes.

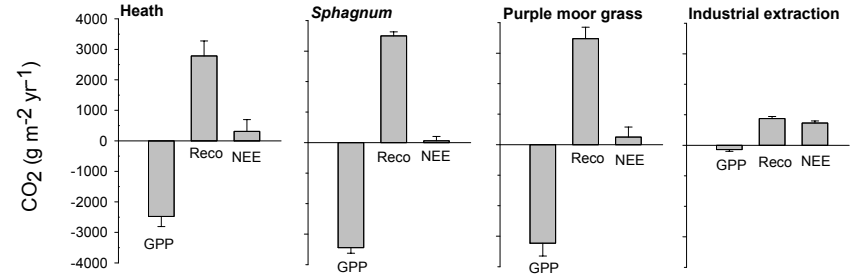

Figure 4. Annual $\mathrm{CO}_{2}$ budgets of four different bog sites in 2011. GPP: gross primary production, Reco: ecosystem respiration and NEE: net ecosystem exchange. Values represent means of the model results of four replicates (plots) at each site \pm SD. Positive values represent emissions and negative values uptakes.

Sphagnum mosses with sedges (Sphagnum site) and nearly monospecific stands of the perennial deciduous grass $M$. caerulea (purple moor grass site). We assume the differences in vegetation composition to be a result of the different water table levels. As the lowest water table position was detected at the purple moor grass site, the combination of both the relatively drier surface and the appearance of the nontypical bog plant resulted in significant differences in GHG fluxes compared to the other two vegetated sites. Here, the highest $\mathrm{CH}_{4}$ fluxes were measured, as well as the highest GPP and highest maximum photosynthetic activity. The fast growth of $M$. caerulea leaves and their autumn senescence can explain the annual dynamics of the modeled NEE at the purple moor grass site. This grass performs no photosynthe- sis in wintertime except at green basal internodes (Jefferies, 1915). Thus, photosynthesis steeply increases with springtime growth and abruptly stops with the dieback of its leaves in fall. By contrast, photosynthesis was detected in wintertime at the Sphagnum and the heath site as they were dominated by evergreen plants.

All three vegetation communities established at the restored study site turned out to be sources of $\mathrm{CO}_{2}$. Thus, restoration failed to re-establish the $\mathrm{CO}_{2}$ sink function after 30 years, in contrast to what was hypothesized. However, the Sphagnum site had the lowest $\mathrm{CO}_{2}$ emissions ranges and, considering the uncertainty related to the spatial variability, close to a $\mathrm{CO}_{2}$ neutral status. These results are concordant with the findings of Samaritani et al. (2010) who showed that a Sphagnum-dominated European mid-latitude cut-over bog, was a $\mathrm{CO}_{2}$ source 29 years after rewetting, but older regenerating sites (42 and 51 years) were taking up $\mathrm{CO}_{2}$. The magnitude of the $\mathrm{CO}_{2}$ balances is consistent with the analyses of 53 studies evaluated by Couwenberg et al. (2008), showing that temperate European peatlands with similar water table positions emit less than $3 \mathrm{tCO}_{2} \mathrm{ha}^{-1} \mathrm{yr}^{-1}$ (utilization and restoration status not mentioned). The net $\mathrm{CO}_{2}$ emissions measured at the industrial extraction site were higher compared to the restored sites, as the soil is deeply drained and only negligible photosynthesis due to algae growth takes place. The annual $\mathrm{CO}_{2}$ emission of $7.3 \mathrm{tCO}_{2} \mathrm{ha}^{-1} \mathrm{yr}^{-1}$ is in the range of 11 reported studies from European drained peat cut sites with a median of 2 and a maximum of 
Table 4. Greenhouse gas (GHG) budgets of four bog sites. The GHG budget of the active industrial extraction site is composed of measured fluxes on site and the $\mathrm{C}$ loss due to peat mining in 2011, assuming its emission as $\mathrm{CO}_{2}$. Values represent means of four $\left(\mathrm{CO}_{2}\right.$ and $\left.\mathrm{CH}_{4}\right)$ or three $\left(\mathrm{N}_{2} \mathrm{O}\right)$ replicates \pm SD.

\begin{tabular}{|c|c|c|c|c|}
\hline Site & \multicolumn{4}{|c|}{$\left(t \mathrm{CO}_{2}\right.$-eq ha $\left.{ }^{-1} \mathrm{yr}^{-1}\right)$} \\
\hline Heath & $3.09 \pm 3.86$ & $21.61 \pm 4.44$ & $-0.07 \pm 0.36$ & $24.63 \pm 5.89$ \\
\hline Sphagnum & $0.60 \pm 1.43$ & $33.87 \pm 23.63$ & $0.16 \pm 0.20$ & $34.62 \pm 23.68$ \\
\hline Purple moor grass & $2.47 \pm 3.30$ & $50.45 \pm 35.56$ & $0.12 \pm 0.36$ & $53.05 \pm 35.72$ \\
\hline \multicolumn{5}{|l|}{ Industrial extraction } \\
\hline On site & $7.30 \pm 0.67^{*}$ & $0.07 \pm 0.22$ & $1.55 \pm 0.81$ & $8.93 \pm 1.07$ \\
\hline Peat mining & $114.02 \pm 6.70$ & & & $114.02 \pm 6.70$ \\
\hline Total & & & & $122.95 \pm 6.78$ \\
\hline
\end{tabular}

* Three replicates.

$13 \mathrm{tCO}_{2} \mathrm{ha}^{-1} \mathrm{yr}^{-1}$ (Drösler et al., 2008). Rewetting of the industrial extraction site provides a $\mathrm{CO}_{2}$ mitigation potential between 422 and $671 \mathrm{~g} \mathrm{CO}_{2} \mathrm{~m}^{-2} \mathrm{yr}^{-1}$ (peat extraction not included) calculated from the $\mathrm{CO}_{2}$ budgets of the three rewetted sites. This is in total 295 to $470 \mathrm{tCO}_{2} \mathrm{yr}^{-1}$ for the whole site (70 ha), depending on which of the three vegetation communities establishes. However, restoring a cut-over peatland requires special techniques as most Sphagnum species cannot re-establish spontaneously and re-vegetation is generally slow due to no viable propagules and unfavorable conditions for plant growth and seed germination (Quinty and Rochefort, 2003; Triisberg et al., 2011; D'Astous et al., 2013).

The GHG budget of the restored site is dominated by $\mathrm{CH}_{4}$ fluxes (up to $98 \%$ ). While the magnitude of the modeled $\mathrm{CO}_{2}$ balances is similar to data reported in other studies as described above, the magnitude of the $\mathrm{CH}_{4}$ fluxes is very high. To our knowledge, the maximum rates reported for European bogs are: approximately $17 \mathrm{tCO}_{2}$-eq ha ${ }^{-1} \mathrm{yr}^{-1}$, which was measured in the Bavarian Alpine foreland on a natural bog site with Sphagnum-Scheuchzeria palustris hollows (Drösler, 2005) and $24 \mathrm{tCO}_{2}$-eq ha ${ }^{-1} \mathrm{yr}^{-1}$ measured in E.vaginatum-colonized infilled ditches of a blanked bog in Wales (Cooper et al., 2014). In the present study, we found annual $\mathrm{CH}_{4}$ fluxes of 22,34 and $51 \mathrm{tCO}_{2}$-eq ha ${ }^{-1} \mathrm{yr}^{-1}$. We hypothesize that the large fluctuations in water level, which are typical for degraded peatlands (Schouwenaars, 1993; Tuittila et al., 1999), might explain these high $\mathrm{CH}_{4}$ emissions as fresh belowground or aboveground plant litter is inundated episodically and undergoes anoxic fermentation (Augustin and Joosten, 2007; Paul and Alewell, 2013). This applies especially for the purple moor grass site although it features the lowest water level of the three vegetated sites: here, $\mathrm{CH}_{4}$ fluxes were higher than at the Sphagnum and the heath site (2.3 and 1.5 times, respectively). We suggest that this is due to the large amounts of litter produced by $M$. caerulea, which is easily decomposable in comparison to other plants present at the study site (van Breemen, 1998). Like we found here, Bohdalkova et al. (2013) observed the highest $\mathrm{CH}_{4}$ emissions at the site with the lowest water level and suggested this to be the result of the invasion of easily degradable vascular plants. Likewise, Hahn-Schöfl et al. (2011) explained extremely high $\mathrm{CH}_{4}$ emissions in a German fen with the inundation of reed canary grass (Phalaris arundinacea). Another likely explanation for the huge $\mathrm{CH}_{4}$ fluxes from the purple moor grass site is the presence of aerenchyma (Jaiswal et al., 2000), through which M. caerulea can act as gas conduit. It hence allows $\mathrm{CH}_{4}$ to bypass the oxidized surface soil, and consequently reduces $\mathrm{CH}_{4}$ oxidation. Although the flux of $\mathrm{CH}_{4}$ through the plant tissues is lower in $M$. caerulea compared to E. angustifolium (Bhullar et al., 2013), the chimney effect might be increased by the high cover of this grass species at the purple moor grass site. Thus, it was shown that in some plots $\mathrm{CH}_{4}$ emissions coincided with high coverage of aerenchymatous plant species. The composition of plant communities is therefore the most important driver for $\mathrm{CH}_{4}$ fluxes at the study sites, as reported by other authors (Samaritani et al., 2010; Couwenberg et al., 2011; Bohdalkova et al., 2013).

Irrespective of the abundance of shunt species, $\mathrm{CH}_{4}$ emissions from the rewetted study site are generally very high. We therefore assume that the site's land use history determines the fundamental conditions for methane production. As mentioned above, the upper vegetated soil layer (Bunkerde) was used for filling up the mined area. We found differently decomposed soil material in layers or lens-shaped zones in the soil profiles of all rewetted sites (data not shown). We hypothesize that the peat material, which was exposed to oxygen, enhances the methanogenic degradation of the organic matter by the initiated decay process (priming process). Additionally, labile organic matter in the form of aboveground plant biomass of the primary vegetation was buried and thus might serve as substrate for $\mathrm{CH}_{4}$ production. A similar effect was found by Cooper et al. (2014), who identified former 
drainage ditches blocked with heather bales and colonized by aerenchymatous species as hotspots for $\mathrm{CH}_{4}$ emissions. However, it must be kept in mind that the heather bales in Cooper et al. (2014) were recently incorporated, while in the present study the incorporation of fresh plant material into the soil is several decades past and can therefore only play a minor role in explaining the high methane emissions found here.

These findings are important for a large area of exploited peatlands, because the peat extraction method applied here was long the traditional way of peat cutting (Koster and Favier, 2005). It is therefore essential that more attention is paid to monitoring and management of areas with a handcutting history. In terms of $\mathrm{CH}_{4}$ mitigation and climate protection, an active reduction of $M$. caerulea stands, by for example sod cutting or grazing, could help to establish target species communities instead (Jacquemart et al., 2003; Reid et al., 2009; Keddy, 2010; Meuser, 2012), and hence reduce $\mathrm{CH}_{4}$ emissions at the study site. Avoiding water table fluctuations is additionally important to impede inundation of fresh plant litter as a substrate for methanogenesis (Hahn-Schöfl et al., 2011). The installation of overflows as management measure could stabilize the water table level (Maitland and Morgan, 1997; Quinty and Rochefort, 2003).

\section{Conclusions}

We found large differences in GHG fluxes between the three vegetation communities. Differentiation between plant communities for estimation and upscaling of GHG budgets is therefore imperative. The particular land use history of this degenerated peat site, in combination with inundation due to water tables fluctuations and a high cover of aerenchymatous plants seem to form favorable conditions for both, high methanogenesis and efficient soil atmosphere $\mathrm{CH}_{4}$ transport. This results in extremely high $\mathrm{CH}_{4}$ emissions and high GHG budgets in comparison to other bog ecosystems in Europe. The annual GHG emissions are at least twice as high as the rates of the industrial extraction site, although 30 years passed since rewetting. We therefore state that the initial increase in $\mathrm{CH}_{4}$ emissions due to rewetting was not limited to a short-term period at our study site, as described in literature. We raise here the question if the emergence of high methane fluxes is, on the contrary, permanent in severely damaged rewetted peatlands, as it is not possible to fully reestablish ecosystem functions.

Acknowledgements. We wish to acknowledge the support of the peat company manager in the Himmelmoor, Klaus Czerwonka, and the committed field and lab assistance of Birgit Grabellus, Mathias Schwarzer, Stephanie Langer and Kira Kalinski. We appreciate the technical support from Christian Wille and Peter Schreiber during the planning and preparation stages of this study. This work was carried out within the research project KLIMZUG-Nord, which was funded by the German Federal Ministry of Education and Research (grant no. 01LR0805D). L. Kutzbach was supported through the Cluster of Excellence "CliSAP" (EXC177) at the University of Hamburg funded through the German Research Foundation.

Edited by: X. Wang

\section{References}

Artz, R. R. E., Chapman, S. J., Saunders, M., Evans, C. D., and Matthews, R. B.: Comment on "Soil $\mathrm{CO}_{2}, \mathrm{CH}_{4}$ and $\mathrm{N}_{2} \mathrm{O}$ fluxes from an afforested lowland raised peat bog in Scotland: implications for drainage and restoration" by Yamulki et al. (2013), Biogeosciences, 10, 7623-7630, doi:10.5194/bg-10-7623-2013, 2013.

Augustin, J. and Joosten, H.: Peatland rewetting and the greenhouse effect, International Mire Conservation Group Newsletter, 3, 2930, 2007.

Averdieck, F.-R.: Zur Geschichte der Moore und Waelder Holsteins: ein Beitrag zur Frage der Rekurrenzflaechen, Nova Acta Leopolina, 130, 27-34, 1957 (in German).

Beyer, C. and Höper, H.: Greenhouse gas exchange of rewetted bog peat extraction sites and a Sphagnum cultivation site in northwest Germany, Biogeosciences, 12, 2101-2117, doi:10.5194/bg12-2101-2015, 2015.

Bhullar, G. S., Edwards, P. J., and Olde Venterink, H.: Variation in the plant-mediated methane transport and its importance for methane emission from intact wetland peat mesocosms, J. Plant Ecol., 6, 298-304, doi:10.1093/jpe/rts045, 2013.

Bohdalkova, L., Curik, J., Kubena, A. A., and Buzek, F.: Dynamics of methane fluxes from two peat bogs in the Ore Mountains, Czech Republic, Plant Soil Environ., 59, 14-21, 2013.

Cooper, M. D. A., Evans, C. D., Zielinski, P., Levy, P. E., Gray, A., Peacock, M., Norris, D., Fenner, N., and Freeman, C.: Infilled Ditches are Hotspots of Landscape Methane Flux Following Peatland Re-wetting, Ecosystems, 17, 1227-1241, doi:10.1007/s10021-014-9791-3, 2014.

Couwenberg, J.: Methane emissions from peat soils (organic soils, histosols), Facts, MRV-ability, emission factors, Wetlands International, Wageningen, the Netherlands, 14 pp., 2009.

Couwenberg, J., Augustin, J., Michaelis, D., Wichtmann, W., and Joosten, H.: Entwicklung von Grundsätzen für eine Bewertung von Niedermooren hinsichtlich ihrer Klimarelevanz, DUENE e.V., Greifswald, 33 pp., 2008 (in German).

Couwenberg, J., Thiele, A., Tanneberger, F., Augustin, J., Bärisch, S., Dubovik, D., Liashchynskaya, N., Michaelis, D., Minke, M., Skuratovich, A., and Joosten, H.: Assessing greenhouse gas emissions from peatlands using vegetation as a proxy, Hydrobiologia, 674, 67-89, doi:10.1007/s10750-011-0729-x, 2011.

D'Astous, A., Poulin, M., Aubin, I., and Rochefort, L.: Using functional diversity as an indicator of restoration success of a cut-over bog, Ecol. Eng., 61, 519-526, doi:10.1016/j.ecoleng.2012.09.002, 2013.

Drösler, M.: Trace gas exchange and climatic relevance of bog ecosystems, Southern Germany, PhD thesis, Lehrstuhl für Vegetationsökologie Department für Ökologie, Technische Universität München, München, 179 pp., 2005. 
Drösler, M., Freibauer, F., Christensen, T., and Friborg, T.: Observations and Status of Peatland Greenhouse Gas Emissions in Europe, The Continental-Scale Greenhouse Gas Balance of Europe, in: Ecological Studies, edited by: Dolman, R. V. H. and Freibauer, A., Springer Science \& Business Media, New York, 243-261, 2008.

Drösler, M., Adelmann, W., Augustin, J., Bergmann, L., Beyer, M., Gibels, M., Förster, C., Freibauer, A., Höper, H., Petschow, U., Hahn-Schöfl, M., Kantelhardt, J., Liebersbach, H., Schägner, J.P., Schaller, L., Sommer, M., Thuille, A., and Wehrhahn, M.: Klimaschutz durch Moorschutz, in: Klimaschutz und Anpassung an die Klimafolgen, edited by: Mahammadzadeh, M., Biebeler, H., and Hubertus B., Institut der deutschen Wirschaft Köln Medien GmbH, Köln, 89-97, 2009 (in German).

Elsgaard, L., Görres, C.-M., Hoffmann, C. C., Blicher-Mathiesen, G., Schelde, K., and Petersen, S. O.: Net ecosystem exchange of $\mathrm{CO}_{2}$ and carbon balance for eight temperate organic soils under agricultural management, Agr. Ecosyst. Environ., 162, 5267, doi:10.1016/j.agee.2012.09.001, 2012.

Erwin, K.: Wetlands and global climate change: the role of wetland restoration in a changing world, Wetl. Ecol. Manag., 17, 71-84, 2009.

Forbrich, I., Kutzbach, L., Hormann, A., and Wilmking, M.: A comparison of linear and exponential regression for estimating diffusive $\mathrm{CH}_{4}$ fluxes by closed-chambers in peatlands, Soil Biol. Biochem., 42, 507-515, 2010.

Freibauer, A., Drösler, M., Gensior, A., and Schulze, E.-D.: Das Potenzial von Wäldern und Mooren für den Klimaschutz in Deutschland und auf globaler Ebene, Natur und Landschaft, 84, 20-25, 2009 (in German)

Görres, C. M., Kutzbach, L., and Elsgaard, L.: Comparative modeling of annual $\mathrm{CO} 2$ flux of temperate peat soils under permanent grassland management, Agr. Ecosyst. Environ., 186, 64-76, doi:10.1016/j.agee.2014.01.014, 2014.

Grand-Clement, E., Anderson, K., Smith, D., Luscombe, D., Gatis, N., Ross, M., and Brazier, R. E.: Evaluating ecosystem goods and services after restoration of marginal upland peatlands in SouthWest England, J. App. Ecol., 50, 324-334, doi:10.1111/13652664.12039, 2013.

Green, S. and Baird, A.: A mesocosm study of the role of the sedge Eriophorum angustifolium in the efflux of methane including that due to episodic ebullition from peatlands, Plant Soil, 351, 207218, doi:10.1007/s11104-011-0945-1, 2012.

Grube, A., Fuest, T., and Menzel, P.: Geology of the Himmelmoor (bog) near Quickborn (Schleswig-Holstein) - Zur Geologie des Himmelmoores bei Quickborn (Schleswig-Holstein), Telma, 40, 19-32, 2010.

Hahn-Schöfl, M., Zak, D., Minke, M., Gelbrecht, J., Augustin, J., and Freibauer, A.: Organic sediment formed during inundation of a degraded fen grassland emits large fluxes of $\mathrm{CH}_{4}$ and $\mathrm{CO}_{2}$, Biogeosciences, 8, 1539-1550, doi:10.5194/bg-8-15392011, 2011.

IPCC: Climate Change 2013: The Physical Science Basis, Contribution of Working Group I to the Fifth Assessment Report of the Intergovernmental Panel on Climate Change, edited by: Stocker, T. F., Qin, D., Plattner, G.-K., Tignor, M., Allen, S. K., Boschung, J., Nauels, A., Xia, Y., Bex, V., and Midgley, P. M., Cambridge University Press, Cambridge, United Kingdom and New York, USA, 1535 pp., 2013.
IUSS: World Reference Base for Soil Resources 2006, World Soil Resources Reports No. 103, FAO, Rome, 128 pp., 2006.

Jacquemart, A.-L., Champluvier, D., and De Sloover, J.: A test of mowing and soil-removal restoration techniques in wet heaths of the High Ardenne, Belgium, Wetlands, 23, 376-385, doi:10.1672/0277-5212(2003)023[0376:atomas]2.0.co;2, 2003.

Jaiswal, V. S.; Rai, A. K.; Jaiswal, U., and Singh, J. S. (Eds.): The changing scenario in plant sciences, Allied Publishers Ltd., New Dehli, 2000.

Jefferies, T. A.: Ecology of the Purple Heath Grass (Molinia Caerulea), J. Ecol., 3, 93-109, doi:10.2307/2962376, 1915.

Joabsson, A., Christensen, T. R., and Wallén, B.: Vascular plant controls on methane emissions from northern peatforming wetlands, Trends Ecol. Evol., 14, 385-388, 1999.

Jonasson, S.: Evaluation of the Point Intercept Method for the Estimation of Plant Biomass, Oikos, 52, 101-106, doi:10.2307/3565988, 1988 .

Joosten, H.: Moorschutz in Europa, Restauration und Klimarelevanz, in: Moore in der Regionalentwicklung, BUND Landesverband Niedersachsen, Wagenfeld/Ströhen, 35-43, 2006 (in German).

Joosten, H. and Clarke, D.: Wise Use of Mires and Peatlands, International Mire Conservation Group and International Peat Society, Saarijärvi, Finland, 304 pp., 2002.

Joosten, H., Tapio-Biström, M.-L., and Tol, S.: Peatlands-Guidance For Climate Change Mitigation Through Conservation, Rehabilitation and Sustainable Use, Mitigation of Climate Change in Agriculture, Volume 5, FAO and Wetlands International, Rome, Italy, 2012 .

Keddy, P. A.: Wetland ecology: principles and conservation, Cambridge University Press, New York, 516 pp., 2010.

Komulainen, V.-M., Nykänen, H., Martikainen, P. J., and Laine, J.: Short-term effect of restoration on vegetation change and methane emissions from peatlands drained for forestry in southern Finland, Can. J. Forest Res., 28, 402-411, doi:10.1139/x98011, 1998.

Koster, E. A. and Favier, T.: Peatlands past and present, in: The physical geography of Western Europe, edited by: Koster, E. A., Oxford University Press, Oxford New York, 161-182, 2005.

Kutzbach, L., Wagner, D., and Pfeiffer, E. M.: Effect of microrelief and vegetation on methane emission from wet polygonal tundra, Lena Delta, Northern Siberia, Biogeochemistry, 69, 341-362, 2004.

Kutzbach, L., Schneider, J., Sachs, T., Giebels, M., Nykänen, H., Shurpali, N. J., Martikainen, P. J., Alm, J., and Wilmking, M.: $\mathrm{CO}_{2}$ flux determination by closed-chamber methods can be seriously biased by inappropriate application of linear regression, Biogeosciences, 4, 1005-1025, doi:10.5194/bg4-1005-2007, 2007.

Lai, D. Y. F.: Methane Dynamics in Northern Peatlands: A Review, Pedosphere, 19, 409-421, doi:10.1016/S1002-0160(09)00003-4, 2009.

Londo, G.: The decimal scale for releves of permanent quadrats, Vegetatio, 33, 61-64, doi:10.1007/bf00055300, 1976.

Maitland, P. S. and Morgan, N. C.: Conservation management of freshwater habitats: lakes, rivers and wetlands, Springer, New York, 233 pp., 1997. 
Meuser, H.: Soil Remediation and Rehabilitation: Treatment of Contaminated and Disturbed Land, Springer, Dordrecht, 408 pp., 2012.

Morison, J. I. L.: Afforested peatland restoration, ClimateXchange, Centre of Expertise on Climate Change, Edinburgh, Scotland, 12 pp., 2012.

Parish, F., A., S., Charman, D., Joosten, H., Minayeva, T., Silvius, M. and Stringer, L. (Eds.): Assessment on peatlands, biodiversity and climate change: main report, Global Environment Centre and Wetlands International, Kuala Lumpur, 179 pp., 2008.

Paul, S. and Alewell, C.: Moorregeneration als Klimaschutzmassnahme: eine Recherche zur neuen Kyoto-Aktivität Wetland Drainage and Rewetting, Bundesamt für Umwelt (BAFU), Abt. Klima. Bern, Schweiz, 45 pp., 2013 (in German).

Pfeiffer, E. M.: Methanfreisetzung aus hydromorphen Böden verschiedener naturnaher und genutzter Feuchtgebiete (Marsch, Moor, Tundra, Reisanbau), Hamburger Bodenkundliche Arbeiten, Hamburg, Germany, 208 pp., 1998 (in German).

Pihlatie, M. K., Christiansen, J. R., Aaltonen, H., Korhonen, J. F. J., Nordbo, A., Rasilo, T., Benanti, G., Giebels, M., Helmy, M., Sheehy, J., Jones, S., Juszczak, R., Klefoth, R., Lobo-do-Vale, R., Rosa, A. P., Schreiber, P., Serca, D., Vicca, S., Wolf, B., and Pumpanen, J.: Comparison of static chambers to measure $\mathrm{CH}_{4}$ emissions from soils, Agr. Forest Meteorol., 171-172, 124-136, doi:10.1016/j.agrformet.2012.11.008, 2013.

Poschlod, P.: Vegetation development of former peat mining areas in the high moors of the bavarian alpine foothills West Germany, Tuexenia, 8, 31-54, 1988.

Quinty, F. and Rochefort, L.: Peatland Restoration Guide, second edition, Canadian Sphagnum Peat Moss Association and New Brunswick Department of Natural Resources and Energy, Québec, 106 pp., 2003.

Reid, N., McEvoy, P. M., and Preston, J. S.: Efficacy of sod removal in regenerating fen vegetation for the conservation of the marsh fritillary butterfly Euphydryas aurinia, Montiaghs Moss Nature Reserve, County Antrim, Northern Ireland, Conservation Evidence, 6, 31-38, 2009.

Richards, F. J.: A Flexible Growth Function for Empirical Use, J. Exp. Bot., 10, 290-301, doi:10.1093/jxb/10.2.290, 1959.

Rodeghiero, M. and Cescatti, A.: Main determinants of forest soil respiration along an elevation/temperature gradient in the Italian Alps, Glob. Change Biol., 11, 1024-1041, doi:10.1111/j.13652486.2005.00963.x, 2005.

Saarnio, S., Alm, J., Silvola, J., Lohila, A., Nykanen, H., and Martikainen, P. J.: Seasonal variation in $\mathrm{CH} 4$ emissions and production and oxidation potentials at microsites on an oligotrophic pine fen, Oecologia, 110, 414-422, 1997.
Samaritani, E., Siegenthaler, A., Yli-Petäys, M., Buttler, A., Christin, P.-A., and Mitchell, E. A. D.: Seasonal Net Ecosystem Carbon Exchange of a Regenerating Cutaway Bog: How Long Does it Take to Restore the C-Sequestration Function?, Restor. Ecol., 19, 480-489, doi:10.1111/j.1526-100X.2010.00662.x, 2010.

Schäfer, C.-M.: Net ecosystem exchange of carbon dioxide and microbial methane dynamics in temperate grasslands on peat, $\mathrm{PhD}$ thesis, Department of Agroecology, University of Aarhus, Denmark, 168 pp., 2012.

Schneider, J., Kutzbach, L., Schulz, S., and Wilmking, M.: Overestimation of $\mathrm{CO}_{2}$ respiration fluxes by the closed chamber method in low-turbulence nighttime conditions, J. Geophys. Res., 114, G03005, doi:10.1029/2008jg000909, 2009.

Schneider, J., Kutzbach, L., and Wilmking, M.: Carbon dioxide exchange fluxes of a boreal peatland over a complete growing season, Komi Republic, NW Russia, Biogeochemistry, 1-29, doi:10.1007/s10533-011-9684-x, 2011.

Schouwenaars, J. M.: Hydrological differences between bogs and bog-relicts and consequences for bog restoration, Hydrobiologia, 265, 217-224, 1993.

Trepel, M.: Zur Bedeutung von Mooren in der Klimadebatte, in: Jahresbericht 2007/2008, Landesamt für Natur und Umwelt des Landes Schleswig-Holstein, Flintbek, 61-74, 2008 (in German).

Triisberg, T., Karofeld, E., and Paal, J.: Re-vegetation of block-cut and milled peatlands: an Estonian example, Mires and Peat, 8, 1-14, 2011.

Tuittila, E. S., Komulainen, V. M., Vasander, H., and Laine, J.: Restored cut-away peatland as a sink for atmospheric $\mathrm{CO}_{2}$, Oecologia, 120, 563-574, 1999.

Tuittila, E.-S., Komulainen, V.-M., Vasander, H., Nykänen, H., Martikainen, P. J., and Laine, J.: Methane dynamics of a restored cutaway peatland, Glob. Change Biol., 6, 569-581, 10.1046/j.13652486.2000.00341.x, 2000.

van Breemen, N.: Plant-induced soil changes: processes and feedbacks, the Netherlands, Kluver Academic Publishers, 264 pp., 1998.

Waddington, J. M. and Day, S. M.: Methane emissions from a peatland following restoration, J. Geophys Res., 112, G03018, doi:10.1029/2007jg000400, 2007.

Wilson, D., Alm, J., Laine, J., Byrne, K. A., Farrell, E. P., and Tuittila, E. S.: Rewetting of Cutaway Peatlands: Are We Re-Creating Hot Spots of Methane Emissions?, Restor. Ecol., 17, 796-806, doi:10.1111/j.1526-100X.2008.00416.x, 2009.

Yli-Petäys, M., Laine, J., Vasander, H., and Tuittila, E. S.: Carbon gas exchange of a re-vegetated cut-away peatland five decades after abandonment, Boreal Environ. Res., 12, 177-190, 2007. 